\title{
Evaluation of the efficiency of consolidants on Hungarian porous limestone by non-destructive test methods
}

\author{
Zita Pápay, Ákos Török \\ Department of Construction Materials and Engineering Geology, \\ Budapest University of Technology and Economics, Budapest
}

Three types of porous limestone from Sóskút quarry and two limestone types obtained directly from Matthias Church of Budapest (both in Hungary) were used to test the performance of five stone consolidants. The quarry specimens were treated under laboratory conditions by saturation. Three types of silicic acid ester, an aliphatic uretan resin and a polymethyl methacrylate were applied to the stone. Physical parameters such as density, porosity, ultrasonic sound velocity and Duroscope rebound value were measured on untreated and treated samples. The absorption rate of different consolidants was also detected. The physical properties of untreated and treated specimens were compared in order to analyze the performance of the consolidants. Duroscope tests have shown that after consolidation there is an increase in surface strength.

Key words: stone consolidation, porous limestone, monuments, density, ultrasonic velocity

\section{Introduction}

The Miocene limestone from Sóskút was one of the most important raw materials for Hungarian architecture in the 19th and 20th centuries (Kertész 1982). Several public buildings and churches were built using this highly porous stone, including the House of Parliament, St. Stephen's Basilica and the Mathias

Addresses: Z. Pápay, Á. Török: H-1111 Budapest, Stoczek u. 2, Hungary, e-mail: zita.papay@googlemail.com, torokakos@mail.bme.hu

Received: January 2, 2008; accepted: April 9, 2008 
Church in Budapest. Miocene porous limestone was also a very popular building material in other parts of the Austro-Hungarian Monarchy during the 19th and 20th centuries: the Opera House in Vienna was constructed with it (Török et al. 2004). Today these monuments exhibit varying degrees of decay, such as disintegration, weathering crust formation, scaling and flaking (Török 2002; Smith et al. 2003). The stone deterioration is caused by air pollution-related chemical and physical changes (Török 2003) as well as by freeze-thaw cycles (Török 2007). Stone consolidation is aimed at slowing down or stopping these adverse processes. The selection of the proper consolidant is one of the key challenges of restoration work. This paper gives an overview of the results of laboratory testing of consolidated and non-consolidated porous limestone samples. The consolidants were selected according to their commercial availability and their usage in stone restoration practice. Accordingly, three types of silicic acid ester, an aliphatic uretan resin and a polymethyl methacrylate were applied on five different types of limestone. The samples were gathered from Sóskút quarry (3 types) and two types of stone were collected from Matthias Church. The main aims of the experiments were to evaluate the performance of the consolidants and to detect physical changes related to consolidation.

Previous studies were carried out which dealt with silicic acid ester consolidation trials of sandstone (Malaga et al. 2004), volcanic tuffs (Wendler et al. 1996; Forgó et al. 2006) and limestone (Kertész 1988; Lukaszewicz 2004). Testing and comparative studies of various consolidants and limestone are also known from earlier studies (Alvarez de Buergo and Fort 2002; Steinhäuser and Wendler 2004; Ahmed et al. 2006). In this study the results are compared to these previous tests and are evaluated with reference to the previous findings. The application of non-destructive laboratory testing in the assessment of the performance of consolidants is also discussed in detail.

\section{Materials}

\section{Limestone}

Textural analyses have shown that the studied porous limestone types are divided into three different fabric categories: i) coarse-grained bioclastic limestone, ii) medium-grained oolitic-micro-oncolitic limestone and iii) finegrained oolitic limestone (Fig. 1). Two types of coarse-grained (represented by the codes $\mathrm{CA}$ and $\mathrm{CB}$ ), a medium-gained (identified with $\mathrm{M}$ ) and two fine-grained types (represented by FA and FB) were used for the laboratory tests (Table 1). The coarse-grained type exhibits a bioclastic ooidal grainstone texture with large (up to $\mathrm{cm}$-size) shell fragments. Its pore system consists of large $\mathrm{mm}$ to $\mathrm{cm}$-size intergranular and smaller intragranular pores. Pore spaces are only partly occluded by sparitic calcite cements; the apparent porosity is 27 to $28 \mathrm{v} \%$, while the effective porosity is only 11 to $17 \mathrm{~m} \%$ (Table 1 ). The medium-grained oolitic limestone (type M) contains well-rounded ooids and micro-oncoids of 

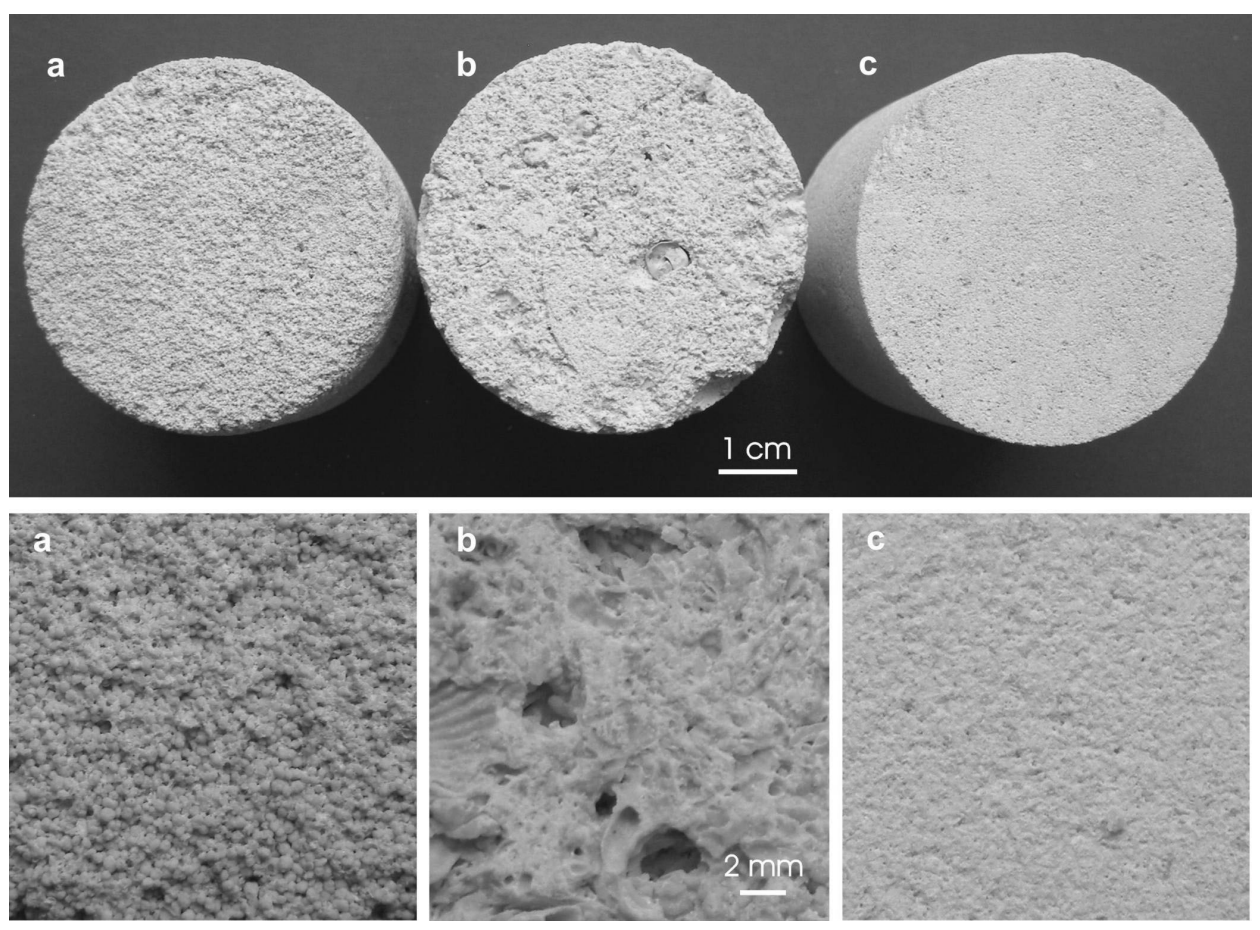

Fig. 1

Fabric of medium (a), coarse (b) and fine-grained (c) limestone types

Table 1

Physical properties of the studied porous limestone types (A: from the quarry, B: from Mathias Church)

\begin{tabular}{|l|c|c|c|c|}
\hline Limestone types & $\begin{array}{c}\text { Symbol } \\
\text { in the text }\end{array}$ & $\begin{array}{c}\text { Density } \\
{\left[\mathrm{g} / \mathrm{cm}^{3}\right]}\end{array}$ & $\begin{array}{c}\text { Apparent } \\
\text { porosity [V\%] }\end{array}$ & $\begin{array}{c}\text { Water absorption } \\
\text { rate [m\%] }\end{array}$ \\
\hline $\begin{array}{l}\text { Fine-grained limestone, } \\
\text { type A }\end{array}$ & $\mathrm{FA}$ & 1.928 & $10-24$ & $4-14$ \\
\hline $\begin{array}{l}\text { Fine-grained limestone, } \\
\text { type B }\end{array}$ & $\mathrm{FB}$ & 1.688 & 30.6 & 19.7 \\
\hline $\begin{array}{l}\text { Medium-grained } \\
\text { limestone }\end{array}$ & $\mathrm{M}$ & 1.644 & 27.3 & 16.3 \\
\hline $\begin{array}{l}\text { Coarse-grained limestone, } \\
\text { type A }\end{array}$ & $\mathrm{CA}$ & 1.572 & 26.9 & 11.1 \\
\hline $\begin{array}{l}\text { Coarse-grained limestone, } \\
\text { type B }\end{array}$ & $\mathrm{CB}$ & 1.680 & 27.9 & 16.6 \\
\hline
\end{tabular}

$0.1-0.3 \mathrm{~mm}$ in diameter. The fabric is ooid grainstone. The pores are mostly intergranular, with mean pore sizes of less than $0.01 \mathrm{~mm}$ (Pápay and Török 2007). A thin rim of sparitic calcite cement is often observed on pore walls. Its apparent porosity is $27 \%$, while its water absorption is just above $16 \%$ (Table 1 ). The two studied fine-grained limestone types have different fabric and physical 
properties. The one from the quarry (FA-type) contains micritized peloids and small ooids with peloidal-ooid grainstone/packstone fabric. According to poresize distribution analyses, the most frequent pores are larger than $0.01 \mathrm{~mm}$, but micro-pores are also very common (Pápay and Török 2007). The apparent porosity and water absorption rate shows large scatter (10-24\% and 4 to $14 \%$, respectively), due to textural differences (Table 1). The other studied fine-grained oolitic limestone (FB-type) is an ooid-grainstone with rounded carbonate particles ooids of $0.05-0.1 \mathrm{~mm}$ in size, apparent porosity of over $30 \%$ and effective porosity of nearly $20 \%$ on average (Table 1 ).

\section{Consolidants}

All the consolidants were used in their liquid form. The most important parameters of the applied consolidants are listed in Table 2. Three consolidants out of the tested five have the same base, silicic acid ethyl (SAE) ester, but the solvents have different rates of dilution. SAE 1 consists of $20 \mathrm{~m} \%$, SAE 2 contains more than $95 \mathrm{~m} \%$, while SAE 3 has $85 \mathrm{~m} \%$ of silicic acid ester (Table 2). The solvent is an aliphatic carbohydrate. Silicic acid esters are compounds of quartz $\left(\mathrm{SiO}_{2}\right)$ and ethyl alcohol $\left(\mathrm{C}_{2} \mathrm{H}_{5} \mathrm{OH}\right)$. The binding mechanism is related to an evaporation process of the solvent and hydrolysis with water vapor. When the alcohol evaporates silica-dioxide is formed in the presence of water vapor. The reaction product is a silica gel that is formed in the pores, providing an additional bond between the particles. The three-dimensional silica gel builds up in several steps and by polymerization processes; it forms gel plates that are chemically bonded with the surfaces of minerals within the pores (Wendler 2001). Aliphatic uretan resin (AUR) as a 50\% solution in white spirit and a polymethyl methacrylate, Paralloid B72 (PMMA) as a 4\% solution in nitro-thinner, was also used for the tests (Table 2).

Table 2

Stone consolidants and their properties

\begin{tabular}{|l|c|c|c|c|}
\hline Consolidant & $\begin{array}{c}\text { Symbol } \\
\text { in the text }\end{array}$ & Diluting agent & Effective agent content $[\mathrm{m} \%]$ & Density $\left[\mathrm{g} / \mathrm{m}^{3}\right]$ \\
\hline Silicic acid ester, type 1 & SAE 1 & ready to use & ca. 20 & 0.79 \\
\hline Silicic acid ester, type 2 & SAE 2 & ready to use & $>95$ & 0.99 \\
\hline Silicic acid ester, type 3 & SAE 3 & ready to use & ca. 85 & 1 \\
\hline Aliphatic uretan resin & AUR & white spirit & 50 & 0.93 \\
\hline Polymethyl methacrylate & PMMA & nitro-thinner & 4 & 0.85 \\
\hline
\end{tabular}

\section{Methods}

Cylindrical specimens with a diameter of $4.5 \mathrm{~cm}$ and a height of $4.5 \mathrm{~cm}$ were used for the tests. Prior to consolidation, trial samples were divided into analytical groups according to their physical parameters, such as apparent 
density and ultrasonic sound velocity. The grouping aimed at minimizing the minor lithological differences, so as to obtain samples with a similar range of properties. The consolidation tests were performed by saturation under atmospheric pressure. Full saturation of the pores was controlled by continuous weight measurements. The physical parameters were analyzed on untreated and treated specimens. Bulk density and apparent porosity were determined according to the MSZ EN 1936:2000 norm. Ultrasonic sound velocity measurements (GeoTron UKS 12-type) were performed following the instructions given by the MSZ EN 14579:2005 standard. Changes in physical parameters, namely density, porosity, water content, and ultrasonic sound velocity were used to evaluate the performance of the consolidants. The efficiency of the strengthening agent is often marked by an increase of the ultrasonic sound velocity (Pápay and Török 2007). Water and consolidant absorption were measured by saturation (norm MSZ EN 13755:2002) and capillary rise (procedure described in norm MSZ EN 1925:2000). Water absorption tests are often applied to test the efficiency of consolidants by comparing the untreated and treated specimens (Meinhart-Degen and Snethlage 2004; Török et al. 2004; Cnudde et al. 2007). The method of capillary rise is aimed at evaluating the penetration depth of the different consolidants in comparison to water (Lukaszewicz 2004). Duroscope rebound test were performed to analyze the surface strength of the samples. The method has been described in details by Török (2003).

\section{Results}

Capillary-rise absorption

Figures 2-6 show the capillary absorption curves of the various consolidants with reference to water absorption of non-treated samples under atmospheric pressure. The graphs illustrate that there are significant differences between the penetration of consolidants within the same type of limestone and in between various limestone types. The steeper curve indicates faster penetration. For all samples water absorption is more rapid than that of consolidants. With one exception (FB-type; Fig. 3) SAE1 shows the most rapid absorption rate among all applied consolidants (Figs 2, 4, 5, 6). The absorption of aliphatic uretan resin (AUR) in tested porous limestone is relatively slow compared to other consolidants (Figs 2, 4,5). The detected capillary rise of AUR is less than $1.5 \mathrm{~cm}$ in 2.5 hours and less than $2 \mathrm{~cm}$ in 24 hours in the FA type limestone (Fig. 2). When comparing the penetration rate of all consolidants in various lithologies, the fastest penetration rate was observed in the fine-grained FB-type (Fig. 3), and the slowest in the fine-grained FA-type (Fig. 2). Independently from the type of stone a decreasing order of absorption rate was detected from SAE, PMMA to AUR, where SAE has the fastest, and AUR the slowest, capillary rise. 


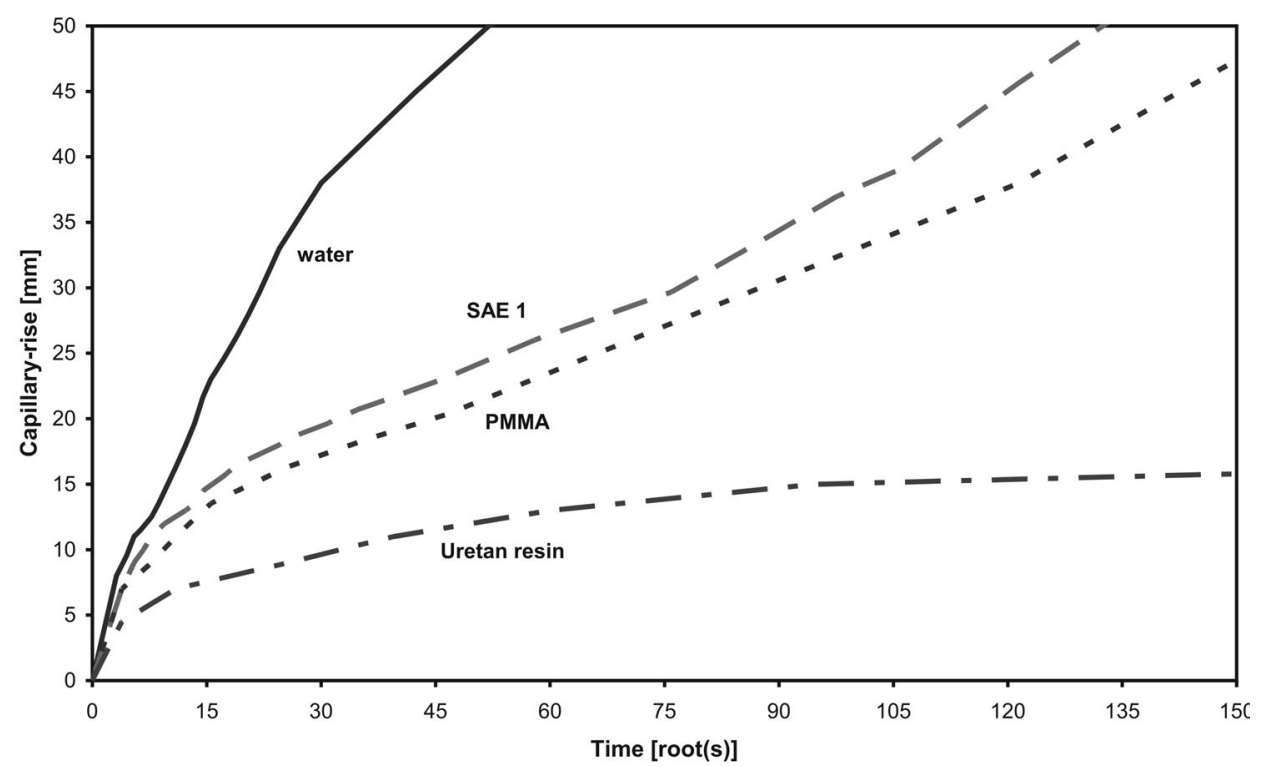

Fig. 2

Capillary-rise absorption of untreated and treated FA-type fine-grained limestone

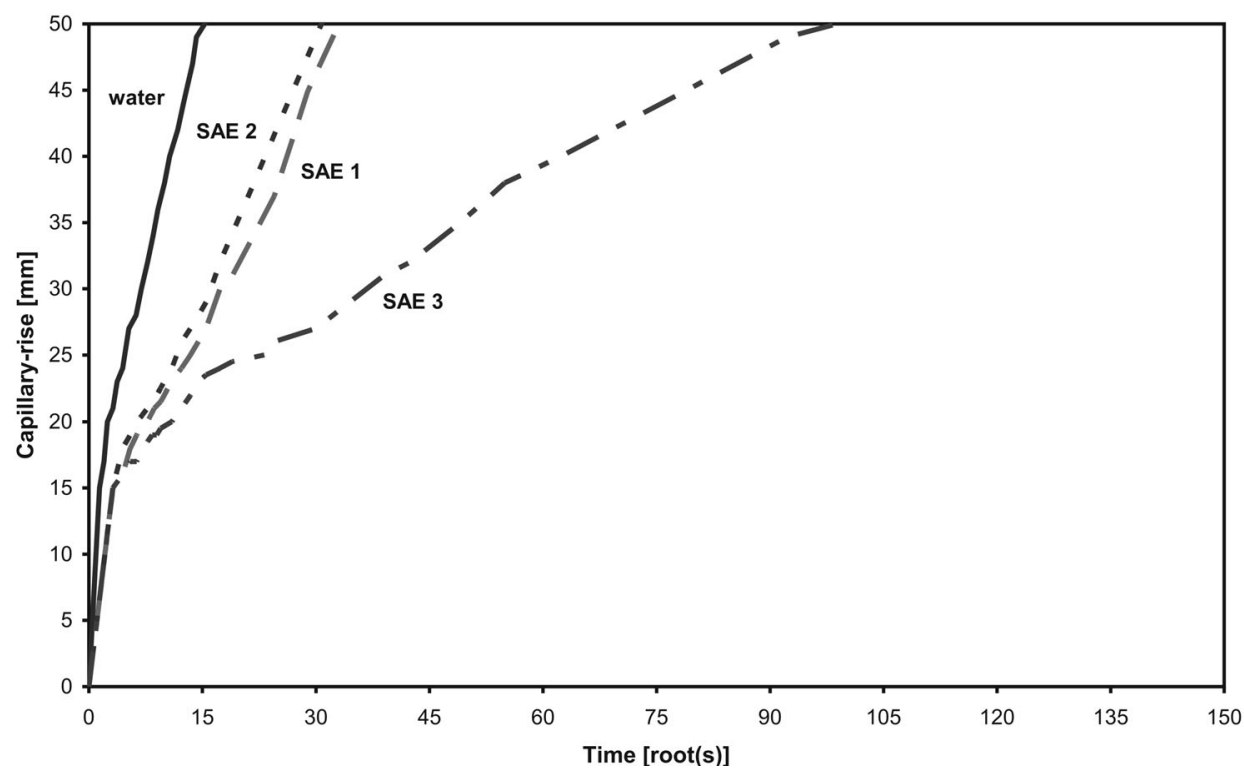

Fig. 3

Capillary-rise absorption of untreated and treated FB-type fine-grained limestone 


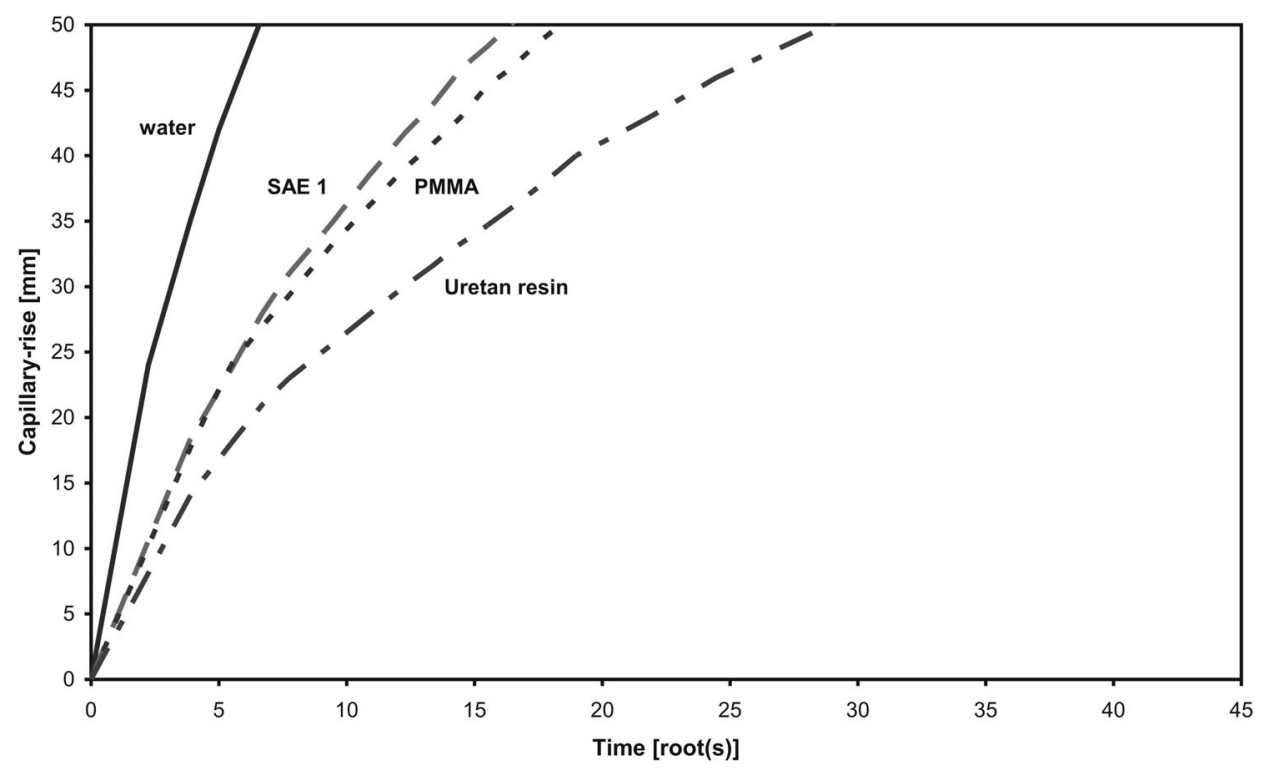

Fig. 4

Capillary-rise absorption of untreated and treated MA-type medium-grained limestone

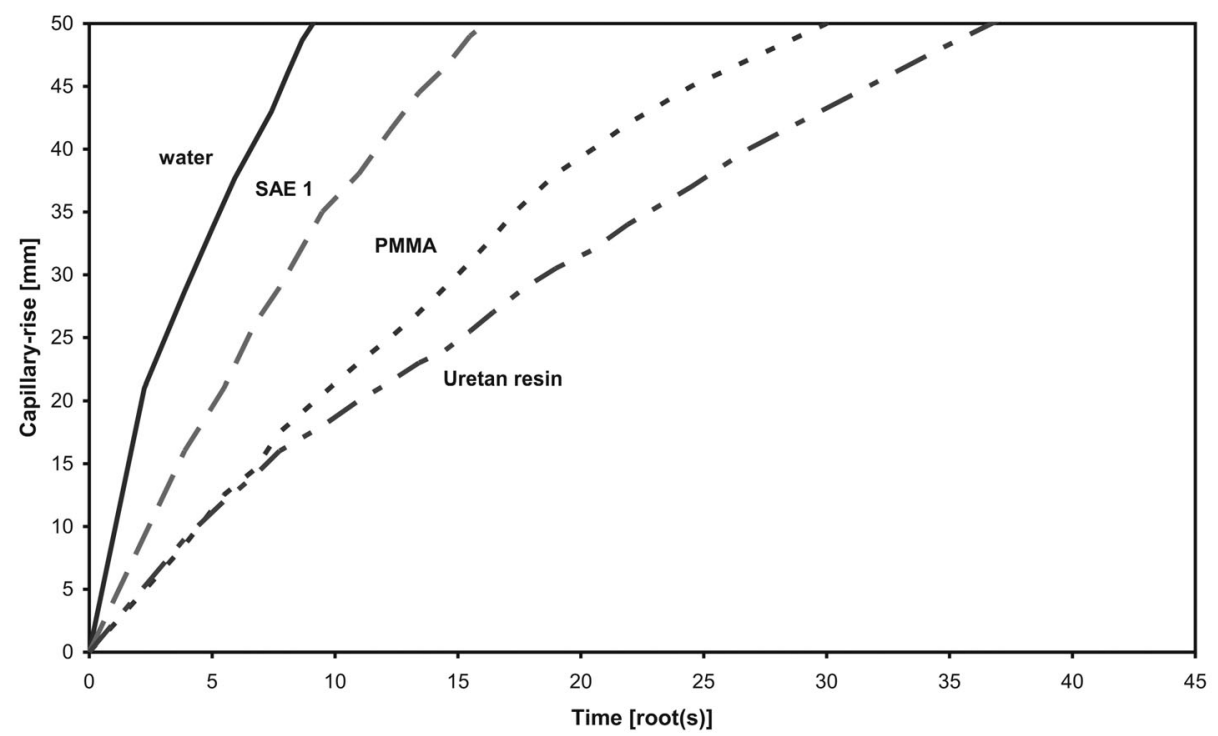

Fig. 5

Capillary-rise absorption of untreated and treated CA-type coarse-grained limestone 


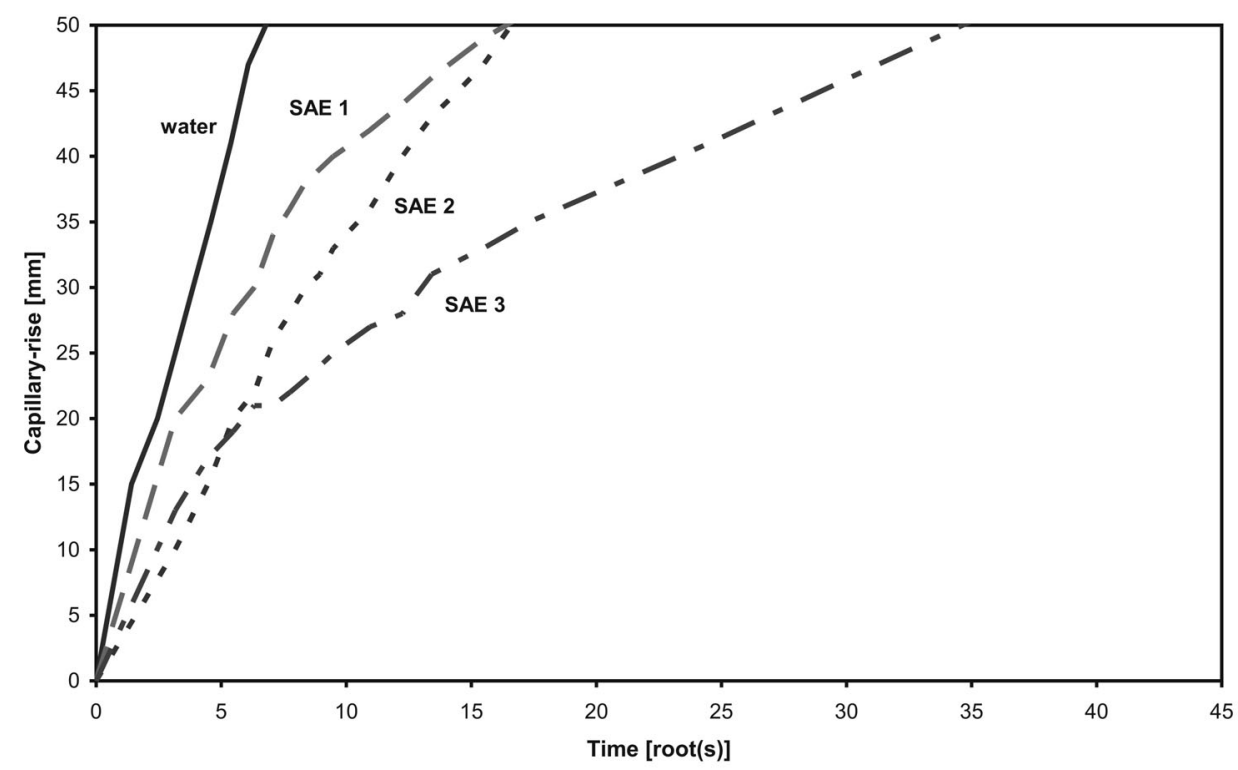

Fig. 6

Capillary-rise absorption of untreated and treated CB-type coarse-grained limestone

\section{Changes in physical properties}

Table 3 summarizes the tested physical parameters. Beside bulk density, the absorbed amount of "wet" consolidant is also listed with reference to the mass of the test samples. Following consolidation, the evaporation of solvent, or after termination of the chemical reactions, the amount of precipitated "solid phase" consolidant, were also documented and then listed in Table 3. When these values of absorbed "wet" consolidant and the percentage of precipitated "solid" consolidant are compared, it becomes clear that from PMMA only 3 to $6 \%$ of solids precipitate in the pores of the limestone, while from AUR 12 to $14 \%$ of resin, and from SAE1 13 to $17 \%$ of silica gel is formed in the pores. From SAE2 nearly $34 \%$ and from SAE3 more than $45 \%$ of silica gel is formed within the pores (Table 3). SAE consolidants increased the density of the porous limestone the most, while AUR caused smaller increase in bulk density values (Table 3).

The increase of the Duroscope rebound values (surface strength) of consolidated samples was the most significant when AUR was applied. Increases of $20.8 \%$ for FA, $140 \%$ for M, $44.4 \%$ for CA were measured (Fig. 7). Negligible changes in Duroscope rebound values were found for one type of fine-grained (FA) and one type of coarse-grained (CA) limestone when SAE 1 was applied (Fig. 7). At the same time increased Duroscope rebound values were measured on SAE 1-treated FB, M and CB limestone types. From these changes it is especially 
Table 3

Physical properties of untreated and consolidated limestone types

\begin{tabular}{|c|c|c|c|c|c|c|}
\hline \multicolumn{2}{|c|}{ Tested stone types } & \multirow{2}{*}{\begin{tabular}{|c}
$\begin{array}{c}\text { Bulk density } \\
{\left[\mathrm{g} / \mathrm{m}^{3}\right]}\end{array}$ \\
1.928
\end{tabular}} & \multirow{2}{*}{$\begin{array}{c}\begin{array}{c}\text { Ultrasonic } \\
\text { sound } \\
\text { velocity } \\
{[\mathrm{km} / \mathrm{s}]}\end{array} \\
2.9\end{array}$} & \multirow{2}{*}{$\begin{array}{c}\text { Absorbed } \\
\text { "wet" } \\
\text { consolidant } \\
{[\mathrm{m} \%]} \\
-\end{array}$} & \multirow{2}{*}{$\begin{array}{c}\begin{array}{c}\text { Percentage of } \\
\text { precipitated } \\
\text { "solid" }\end{array} \\
\text { consolidant }[\mathrm{m} \%] \\
-\end{array}$} & \multirow{2}{*}{$\begin{array}{c}\begin{array}{c}\text { Duroscope } \\
\text { rebound } \\
\text { value }\end{array} \\
24 \\
\end{array}$} \\
\hline \multirow{4}{*}{$\begin{array}{l}\text { Fine-grained } \\
\text { limestone, } \\
\text { type A (FA) }\end{array}$} & untreated & & & & & \\
\hline & SAE 1 & 2.034 & 3.4 & 5.0 & 0.86 & 24 \\
\hline & AUR & 1.939 & 3.3 & 4.0 & 0.56 & 29 \\
\hline & PMMA & 1.941 & 3 & 7.7 & 0.43 & 25 \\
\hline \multirow{4}{*}{$\begin{array}{l}\text { Fine-grained } \\
\text { limestone, } \\
\text { type B (FB) }\end{array}$} & untreated & 1.688 & 1.9 & & - & 6 \\
\hline & SAE 1 & 1.729 & 1.8 & 14.1 & 2.16 & 13 \\
\hline & SAE 2 & 1.791 & 1.7 & 17.5 & 6.06 & 11 \\
\hline & SAE 3 & 1.824 & 1.9 & 17.5 & 8.26 & 14 \\
\hline \multirow{4}{*}{$\begin{array}{c}\text { Medium- } \\
\text { grained } \\
\text { limestone }(\mathrm{M})\end{array}$} & untreated & 1.644 & 2.5 & - & & 5 \\
\hline & SAE 1 & 1.720 & 2.9 & 10.9 & 1.77 & 6 \\
\hline & AUR & 1.723 & 2.8 & 12.7 & 1.66 & 12 \\
\hline & PMMA & 1.652 & 2.5 & 13.3 & 0.48 & 10 \\
\hline \multirow{4}{*}{$\begin{array}{c}\text { Coarse-grained } \\
\text { limestone, } \\
\text { type A (CA) }\end{array}$} & untreated & 1.572 & 2.4 & & - & 9 \\
\hline & SAE 1 & 1.591 & 2.7 & 12.4 & 2.12 & 9 \\
\hline & AUR & 1.600 & 2.7 & 14.4 & 1.72 & 13 \\
\hline & PMMA & 1.602 & 2.8 & 13.0 & 0.35 & 9 \\
\hline \multirow{4}{*}{$\begin{array}{c}\text { Coarse-grained } \\
\text { limestone, } \\
\text { type B (CB) }\end{array}$} & untreated & 1.680 & 2.3 & - & - & 10 \\
\hline & SAE 1 & 1.703 & 2.3 & 11.4 & 1.44 & 13 \\
\hline & SAE 2 & 1.763 & 2.2 & 14.0 & 4.7 & 13 \\
\hline & SAE 3 & 1.810 & 2.3 & 14.7 & 6.90 & 12 \\
\hline
\end{tabular}

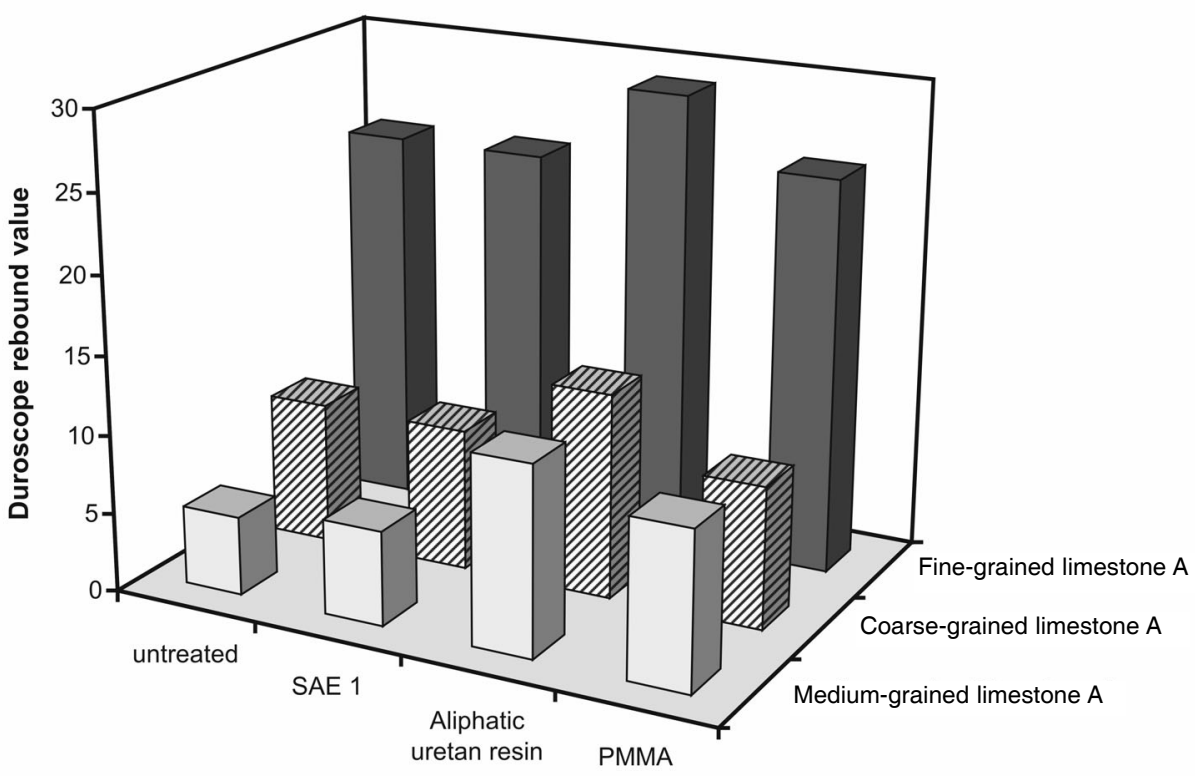

Fig. 7

Duroscope rebound values of untreated and treated limestone types 
noticeable that the rebound value more than doubled with SAE 1-treated FB limestone (Table 3). The same trend was observed for SAE 2 and SAE 3-treated fine-grained FB limestone, while the increase in Duroscope rebound values are far less for the coarse-grained lithotypes with respect to SAE treatments (Fig. 8).

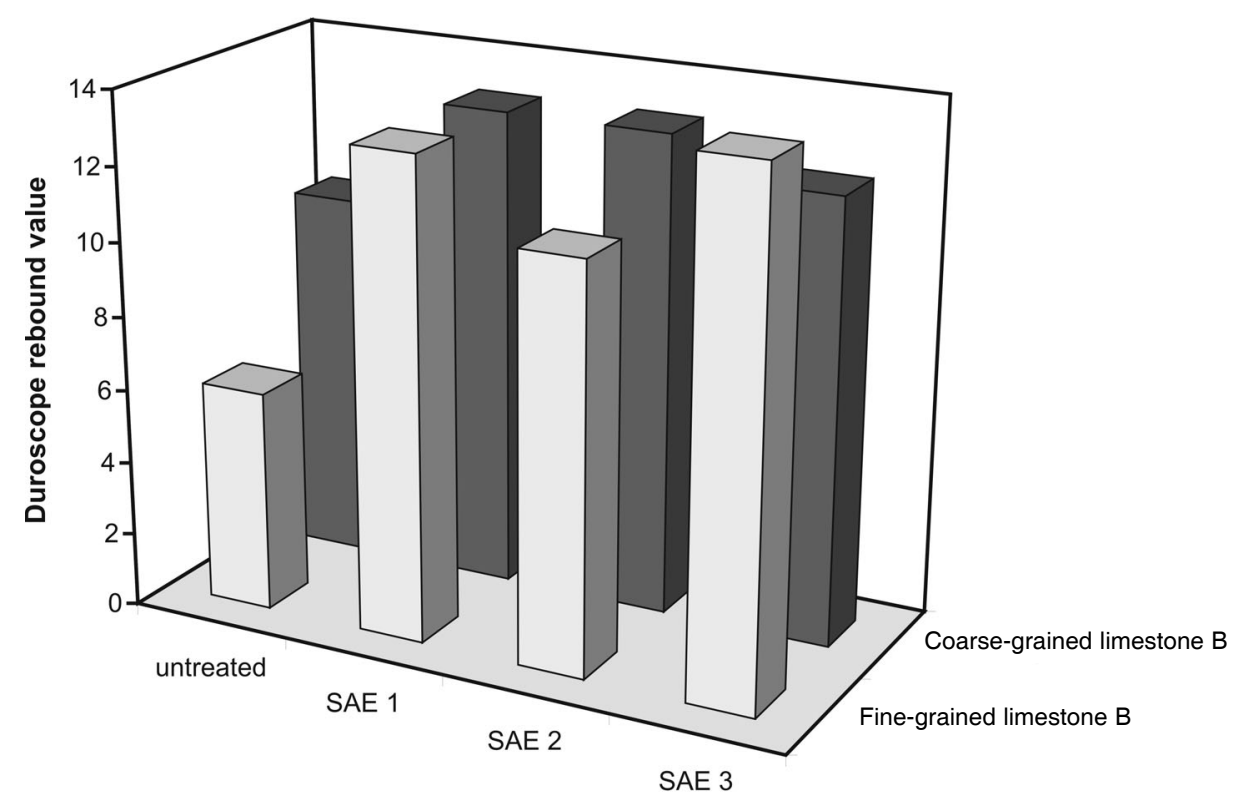

Fig. 8

Duroscope rebound values of untreated and SAE treated limestone types

Ultrasonic sound velocities do not reflect the same trend as Duroscope rebound values. Slight increase in velocities were measured for SAE 1-treated specimens (with one exception), while specimens that were consolidated by using AUR and PMMA show $12.0-13.8 \%$ and $0-16.7 \%$ of positive change in ultrasonic sound velocities (Table 3, Fig. 9).

\section{Discussions}

Of all tested consolidants the SAE ones show the fastest absorption rate. This can be explained by the properties of the SAE fluid. Although the density of SAE is the highest among the tested consolidants (Ahmed et al. 2006) its viscosity is in the order of $2.8 \mathrm{mPas}$, which is one of the lowest. Indeed SAE has a far greater capability of penetrating smaller pores as well as the ability to fill micropores, resulting in a more rapid capillary rise, and in a pumping force that allows rapid capillary rise. The properties of liquid ready-to-use SAE are thus more similar to water than that of the other consolidants. AUR and PMMA are dissolved in 


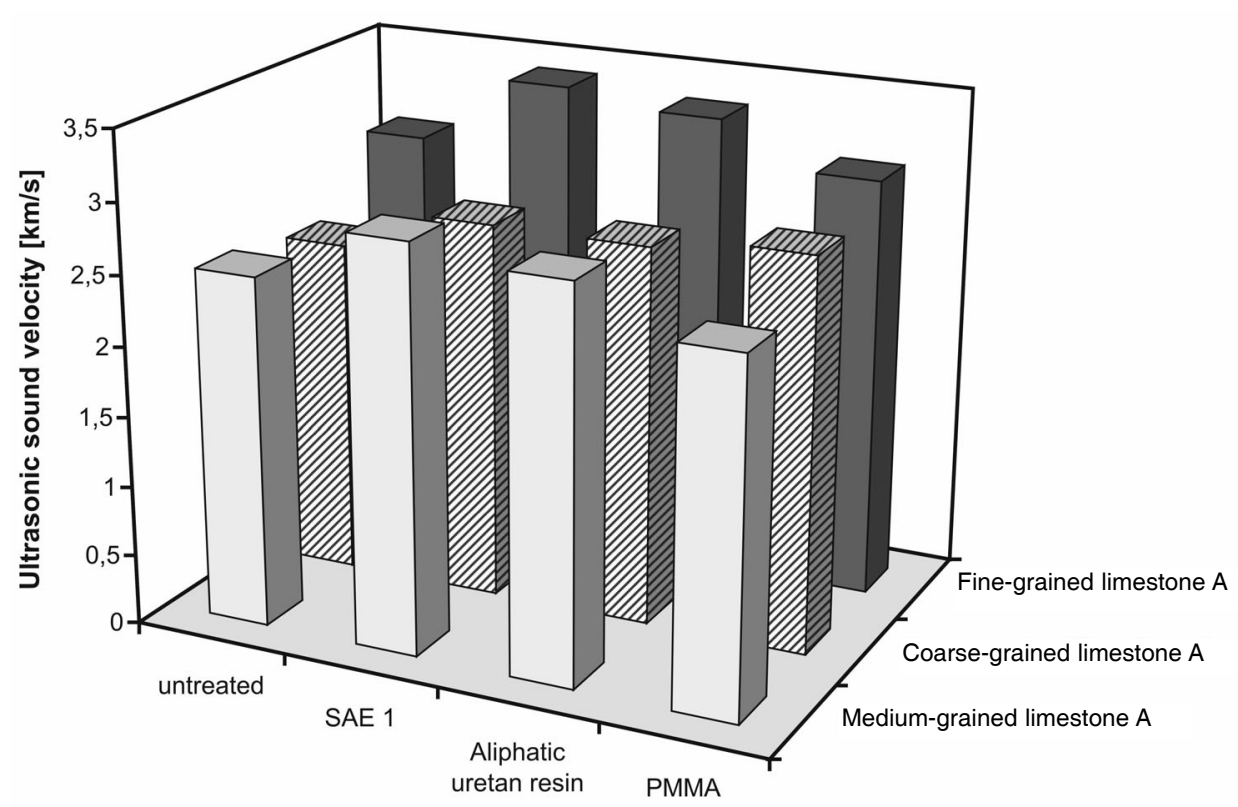

Fig. 9

Ultrasonic pulse velocities of untreated and treated limestone types

various solvents prior to their usage and these solvents moisturize the pore walls less than SAE, causing slower capillary rise of these consolidants. Fabric and pore-size distribution significantly control the absorption properties of stone. When the pore-size distribution of the tested limestone types are considered, the previous test showed that in fine-grained limestone (FA-type) pores larger than $10 \mu \mathrm{m}$ are the most common (Pápay and Török 2007), while in the coarse-gained type, although larger individual pores are found, pore sizes in the order of $10 \mu \mathrm{m}$ are less common (Török et al. 2007). Water absorption tests have shown that finegrained types are subject to slower absorption compared to medium and coarsegrained ones (Figs 2-6). Although the absorption is slower, fine-grained types (especially the FB-type), due to its high porosity absorbs significant amounts of water and consolidants (Table 1 and Table 3). Consequently the pore size distribution is responsible for water transport properties of stone (Fitzner and Basten 1994) and thus significantly influences the durability as well. The consolidation causes a shift in pore size distribution (Hilbert 1999; Wendler 2001; Forgó et al. 2006). The change of pore size distribution depends not only on the molecule size of the particular consolidant, but also on the binding mechanism and on the post-consolidation processes acting in the consolidants (Hilbert 1999).

The amount of absorbed consolidant is not necessarily proportional to the increase in physical parameters. When changes in density are considered it seems that, for most tested stone types, SAE caused the greatest increase in density. This 
corresponds to the highest increase in ultrasonic sound velocity (Table 3, Fig. 9). However, Duroscope rebound values (i.e. surface strength values) increase the most with AUR-treated samples and not with SAE-treated ones. This fact can be explained by the different nature of SAE and AUR. While SAE can penetrate into smaller pores and pores that are found within the specimens, AUR often forms a cemented zone in the outer layers of samples and does not penetrate deeply. This causes an increase in surface strength (Fig. 7), but a less significant augmentation of ultrasonic pulse velocity (Fig. 9) than SAE. The smallest increase in ultrasonic pulse velocity indicates deep-lying pores that were not filled by AUR.

It appears that the stone can absorb higher amounts of liquid-phase PMMA than SAE, but a larger amount of precipitated solid-phase SAE than of PMMA was found in the pores of tested limestone types (Table 3). Thus the liquid phase of PMMA evaporates more readily than that of SAE, and a greater amount of solid-phase SAE consolidant remains in the pores. With one exception this can be shown from ultrasonic pulse velocities, since SAE-treated samples have higher US values (Fig. 9). Duroscope rebound values do not reflect a clear trend from that point of view. When the various SAE consolidants are compared (Table 2) it seems that SAE 2, in which the highest amount of silicic acid ester $(95 \mathrm{~m} \%)$ is found, did not necessarily cause the highest increase in Duroscope rebound and US velocities. For fine-grained limestone types, however, SAE 3 (which contains $85 \mathrm{~m} \%$ ), and for coarse-grained limestone SAE 1 (which has the lowest silica acid ester content with $20 \mathrm{~m} \%$ ), were the most effective (Table 3, Fig. 8). Consequently, according to laboratory tests it is necessary to adjust the silica acid ester content of the SAE consolidant for each type of porous limestone.

The experiments listed above demonstrate the importance of laboratory consolidation trials before in situ application of any consolidant on monument stone.

\section{Conclusions}

Porosity, and especially pore-size distribution, of these limestone types controls the absorption capacity of water and consolidants. The amount of absorbed consolidant is not inevitably proportional to the increase in physical parameters. This depends on several parameters, including the ability of the consolidant to penetrate into pores, the variable evaporation rate of solvents of the consolidants, and the different mechanisms of chemical bonding between the consolidant and stone. SAE, and especially the dilute form of SAE ( $20 \mathrm{~m} \%$ silica acid ester content), has the highest penetration rate of all tested consolidants. From the absorbed $5-14.1 \%$ of SAE, approximately 0.9 to $2.2 \%$ of solid phase silica gel is formed within the pores of limestone. AUR forms a cemented crust on the test samples, causing an increase in surface strength but a less significant increase in ultrasonic pulse velocities. PMMA seems to be less effective in consolidating these porous limestone types. The laboratory tests have proved that prior to stone 
consolidation in monuments, it is necessary to carry out laboratory test trials to select the most appropriate consolidants, since no 'universal' recipe is known for any stone type. Additionally, these tests have demonstrated that commonly used non-destructive tests do not necessarily reflect the efficiency of consolidation.

\section{Acknowledgements}

The financial support of the Hungarian Science Fund (OTKA, K63399) is acknowledged. E. Kovács-Sebestyén, Gy. Emszt, E.L. Árpás and S. Polányi helped during the laboratory testing.

\section{References}

Ahmed, H., Á. Török, J. Lốcsei 2006: Performance of some commercial stone consolidating agents on porous limestones from Egypt. - In: Fort, R, M. Alvarez de Buegom, M. Gomez-Heras, C. Vazquez-Calvo (Eds): Heritage Weathering and Conservation, Taylor and Francis/Balkema, London. Vol. II, pp. 735-740.

Alvarez de Buergo, M., R. Fort 2002: Characterizing the construction materials of a historic building and evaluating possible preservation treatments for restoration purposes. - In: Siegesmund, S. T.S. Weiss, A., Vollbrecht (Eds): Natural Stones, Weathering Phenomena, Conservation Strategies and Case Studies. Geological Society, London, Special Publications 205, pp. 241-254.

Cnudde, V., M. Dierick, J. Vlassenbroeck, B. Masschaele, E. Lehmann, P. Jacobs, L. Van Hoorebeke 2007: Determination of the impregnation depth of siloxanes and ethylsilicates in porous material by neutron radiography. - Journal of Cultural Heritage, 8, pp. 331-338.

Fitzner, B., D. Basten 1994: Gesteinsporosität - Klassifizierung, meßtechnische Erfassung und Bewertung ihrer Verwitterungsrelevanz. - Jahresberichte aus dem Forschungsprogramm "Steinzerfall - Steinkonservierung" 1992, pp. 19-32, Förderprojekt des Bundesministers für Forschung und Technologie, Verlag Ernst \& Sohn, Berlin.

Forgó, L.Z, H. Stück, E. Maróthy, S. Siegesmund, Á. Török, J. Rüdrich 2006: Materialverhalten von natürlichen and modellhaft konsolidierten Tuffen. - In: Auras, M., R. Snethlage (Eds): Denkmalgestein Tuff. Institut für Steinkonservierung, Mainz, Bericht Nr. 22, pp. 65-75.

Hilbert, G. 1999: Natursteinkonservierung. - Mittel und Durchführung. Naturstein, 2, pp. 44-49.

Kertész, P. 1982: A Múemléki kőanyagok bányahelyeinek kutatása (Research of ancient quarries of monumental stones). Építés-Építészettudomány, 1-2, pp. 193-228. (In Hungarian.)

Kertész, P., 1988: Decay and conservation of Hungarian building stones. - In: Marinos, P.G., G.C. Koukis (Eds): The Engineering Geology of Ancient Works, Monuments and Historical Sites. IEAG Conference Proceedings, Athens, Balkema, Rotterdam, II, pp. 755-761.

Lukaszewicz, J.W. 2004: The efficiency of the application of tetraethoxysilane in the conservation of stone monuments. - In: Kwiatkowski, D., R. Löfvendal (Eds): Proceedings of the 10th International Congress on Deterioration and Conservation of Stone. ICOMOS Sweden Stockholm, Vol. I, pp. 479-486.

Malaga, K., M. Myrin, J.E. Lindqvist 2004: Consolidation of Gotland sandstone. - In: Kwiatkowski, D., R. Löfvendal (Eds): Proceedings of the 10th International Congress on Deterioration and Conservation of Stone. ICOMOS Sweden, Stockholm, Vol. I, pp. 447-454.

Meinhardt-Degen, J., R. Snethlage 2004: Durability of hydrophobic treatment of sandstone facades investigation of the necessity and effects of re-treatment. - In: Kwiatkowski, D., R. Löfvendal (Eds): Proceedings of the 10th International Congress on Deterioration and Conservation of Stone. ICOMOS Sweden, Stockholm, Vol. I, pp. 347-354.

Pápay, Z., Á. Török 2007: The effect of stone consolidation on the physical properties of porous limestone. A rock mechanical approach. - In: Sousa, L.R.E., C. Olalla, N.F. Grossmann (Eds): 
11th Congress on the International Society for Rock Mechanics. Taylor and Francis, London, Vol. 1, pp. 465-467.

Smith, B.J., Á. Török, J.J. McAlister, J. Megarry 2003: Observations on the factors influencing stability of building stones following contour scaling: a case study of the oolitic limestones from Budapest, Hungary. - Building and Environment, 38/9-10, pp. 1173-1183.

Steinhäuser, U., E. Wendler 2004: Conservation of limestone by surfactants and modified ethylsilicates. - In: Kwiatkowski, D., R. Löfvendahl (Eds): 10th International Congress on Deterioration and Conservation of Stone - Stockholm 2004, ICOMOS Sweden, Stockholm, pp. 439-446.

Török, Á. 2002: Oolitic limestone in polluted atmospheric environment in Budapest: weathering phenomena and alterations in physical properties. - In: Siegesmund, S., T.S. Weiss, A. Vollbrecht (Eds): Natural Stones, Weathering Phenomena, Conservation Strategies and Case Studies. Geological Society, London, Special Publications, 205, pp. 363-379.

Török, Á. 2003: Surface strength and mineralogy of weathering crusts on limestone buildings in Budapest. - Building and Environment, 38/9-10, pp. 1185-1192.

Török, Á. 2007: Morphology and detachment mechanism of weathering crusts of porous limestone in the urban environment of Budapest. - Central European Geology, 50, 3, pp. 225-240.

Török, Á., N. Rozgonyi 2004: Mineralogy and morphology of salt crusts on porous limestone in urban environment. - Environmental Geology, 46, 3, pp. 323-339.

Török, Á., N. Rozgonyi, R. Prikryl, J. Prikrylová 2004: Leithakalk: the ornamental and building stone of Central Europe, an overview. - In: Prikryl, R. (Ed.): Dimension Stone. Balkema, Rotterdam, pp. 89-93.

Török, Á., M. Gálos, K. Kocsányi-Kopecskó 2004: Experimental weathering of rhyolite tuff building stones and effect of an organic polymer conserving agent. - In: Smith, B.J., A.V. Turkington (Eds): Stone Decay, Its Causes and Controls. Donhead, Dorset, pp. 109-127.

Török, Á., C. Müller, A. Hüpers, M. Hoppert, S. Siegesmund, T. Weiss. 2007: Differences in texture, physical properties and microbiology of weathering crust and host rock: a case study of the porous limestone of Budapest (Hungary). - In: Prykril, R., J.B. Smith (Eds): Building Stone Decay: From Diagnosis to Conservation. Geological Society, London, Special Publications 271, pp. 261-276.

Wendler, E. 2001: Elastifizierte Kieselsäureester als mineralische Bindemittel für unterschiedliche Konservierungsziele. Praktische Erfahrungen mit dem KSE-Modulsystem.

Natursteinkonservierung: Grundlagen, Entwicklungen und Anwendungen. - WTASchriftenreihe, Aedificatio, Freiburg, 23, pp. 55-78.

Wendler, E., A.E. Charola, B. Fitzner 1996: Easter Island Tuff: Laboratory studies for its consolidation. - In: Riederer, J. (Ed.): Proceedings of the 8th International Congress on Deterioration and Conservation of Stone, Berlin, 30.9.-4.10.1996, Vol. 2, pp. 1159-1170. 